\title{
NATURAL RESEEDING IN PERENNIAL RYEGRASS/WHITE CLOVER DAIRY PASTURES
}

P. J. L'Huillier and D. W. Aislabie

Ruakura Dairy Research Centre, MA F, Hamilton

\begin{abstract}
The extent to which propagation of perennial ryegrass from seed can contribute to sward stability and the influence on this of spring pasture management, seedling competition and seed viability and losses was examined in a replicated plot experiment.

Under hard grazing in late spring less than $5 \%$ of reproductive tillers reached flowering. Where grazing was restricted during reproductive tiller development to allow reseeding, $80-90 \%$ of tillers flowered. Subsequent seedling densities were 20-50 times higher and herbage accumulation during late summer-early winter was $33 \%$ greater on plots reseeded than those hard grazed in spring.

Farm practices such as hard grazing, topping and possibly silage conservation which remove reproductive tillers before flowering will greatly reduce ryegrass reseeding and may contribute to the poor persistence of ryegrass wards under intensive dairy cattle grazing.
\end{abstract}

Keywords: grassland management, propagation, botanical composition, herbage accumulation. soil seed dynamics.

\section{INTRODUCTION}

The persistence of perennial tyegrass (Lolium perenne), the major grass sown in New Zealand pasture (Lancashire 1985), relates predominantly to its ability to spread by vegetative tillering (Langer 1973). Its propagation from seed is not considered to be important in established swards (Chancellor 1979), since first perennial ryegrass seed does not possess after ripening or dormancy mechanisms (Thompson \& Grime 1979) and therefore does not accumulate reserves in the soil, and second, in intensively managed grassland farming systems the development of reproductive tillers is associated with a decline in sward quality. The objective of this experiment is to examine the extent to which propagation of tyegrass from seed contributes to sward persistence of a ryegrass based dairy pasture and the influence on this of spring pasture management, seedling competition and seed viability and losses.

\section{MATERIALS AND METHODS}

Site

The experiment was conducted at the Ruakura Dairy Research Centre, Hamilton. The soil was an imperfectly drained Te Kowhai silt loam. Pastures were perennial ryegrass and white clover dominant and had received common management for 2 years prior to the experiment.

\section{Design and treatments}

A randomised block design with four replicates was used (plot size: $120 \mathrm{~m}^{2}$ ). Treatments imposed from 1 September 1986 to 12 January 1987 were

1. Hard grazing with topping - residual herbage mass (RHM) $1500 \mathrm{~kg} \mathrm{DM} / \mathrm{ha}$ with topping to $5 \mathrm{~cm}$ after grazing.

2. Hard grazing - RHM: $1500 \mathrm{~kg} \mathrm{DM} / \mathrm{ha}$

3. Lax grazing - RHM: $2500 \mathrm{~kg}$ DM/ha.

4. Partial reseeding - plots restricted from grazing during reproductive tiller development but with one extra grazing 28 days after reproductive meritstem (developing seedhead) reached grazing height (11 November 1986 to 12 January 1987). 
5. Complete reseeding - plots restricted from grazing throughout reproductive tiller development, 13 October 1986 to 12 January 1987.

Plots were grazed every 28 days during spring and 34 days during late summer-early winter.

\section{Measurements}

Herbage accumulation of each plot was calculated from measurements of herbage mass before and after grazing using a pasture probe. The mean of 30 randomly located meter readings per plots was converted to $\mathrm{kg} \mathrm{DM} / \mathrm{ha}$ using a calibration equation $\left(\mathrm{r}^{2}=0.85\right.$

0.97 ) established from fifteen $0.25 \mathrm{~m}^{2}$ quadrats located in adjacent pasture. A common calibration equation was used for all treatments as differences between treatments were not significant.

Botanical composition of each plot was determined before and after grazing during the treatment period (spring) and subsequently every 6 weeks, from a near ground level clip sample. A subsample was used for in vitro digestibility determinations. Grass tiller and white clover node density of each plot was determined every 6 weeks, from four $20 \times 5 \mathrm{~cm}$ randomly located frames per plot. Reproductive tiller development and fate was examined on 10 tagged tillers per plot (40 per treatment) located at $1 \mathrm{~m}$ intervals along a $10 \mathrm{~m}$ transect

Viable ryegrass seed density in the soil was determined on 1 September 1986, 12 January 1987 , and 1 July 1987 . Ten $5 \times 5 \mathrm{~cm}$ soil cores were taken per plot. The number of viable ryegrass seeds was determined by counting seeds that germinated (Thompson \& Grime 1979).

Fate of ryegrass seed on the soil surface was monitored on three $30 \mathrm{~cm}$ dia. wire quadrats located in plots of treatment 3 (hard grazed plus topping). One thousand ryegrass seeds (hand harvested from adjacent areas) were evenly spread over each frame on 12 January 1987. Germinated seedlings, ungerminated seed, seed removed and dead were monitored.

Ryegrass seedling survival was monitored on each plot after late summer rain. Seedlings within six $15 \mathrm{~cm}$ dia. fixed frames per plot were marked with plastic coated wire and observed every 4 weeks.

\section{RESULTS}

\section{Sward composition, herbage accumulation and reproductive tiller development}

As the defoliation intensity decreased from hard grazing with topping to complete reseeding, the proportion of ryegrass leaf, paspalum and white clover decreased, whereas ryegrass reproductive stem and dead material increased (Table 1). In vitro-digestibility differences between treatments were not significant (Table 1). Similarly, the rates of accumulation of grass leaf and green herbage increased, grass reproductive stem and dead material decreased and grass pseudostem, white clover and total herbage were not significantly different (Table 2).

Herbage accumulation in late summer-early winter (19 January to 1 July 1987) was greater in laxly graxed and partially and completely reseeded pasture in spring than those hard grazed and topped (Table4).

Further, as the defoliation intensity decreased, the proportion of reproductive tillers intact at flowering, the density of intact tillers and density of viable ryegrass seeds increased (Table 3).

\section{Seed viability and losses}

Ryegrass seed harvested from areas adjacent to plots, germinated rapidly when placed on hard grazed and topped plots in mid-January. Within 6 weeks of placement, $55 \pm 4 \%$ of total seed had germinated. Of the remaining seed $37 \pm 2 \%$ had not germinated after 5 months, only $7 \pm 3 \%$ of this was encouraged by chilling $\left(3-4\right.$ days at $\left.4^{\circ} \mathrm{C}\right)$. The remaining $8 \pm$ $2 \%$ of total seed disappeared. 
Table I: Pasture composition (\% of DM) and I" vitro digestibility percentage immediately prior to grazing of reseeded pastures (12 January 1967)

\begin{tabular}{|c|c|c|c|c|c|c|c|}
\hline & $\begin{array}{c}\text { Hard } \\
\text { grazing } \\
\text { +topping }\end{array}$ & $\begin{array}{l}\text { Hard } \\
\text { grazıng }\end{array}$ & $\begin{array}{r}\text { Lax } \\
\text { grazing }\end{array}$ & $\begin{array}{c}\text { Partial } \\
\text { reseeding }\end{array}$ & $\begin{array}{l}\text { Complete } \\
\text { reseeding }\end{array}$ & SED & Sign \\
\hline Ryegrass: leaf & 36 & 27 & 11 & 6 & 9 & 3 & + \\
\hline pseudostem & 8 & 10 & 3 & I & 3 & 1 & *" \\
\hline reprod. stem & 3 & 12 & 34 & 45 & 30 & 7 & .. \\
\hline Paspalum & 26 & 20 & 15 & 6 & 10 & 4 & .. \\
\hline Other grasses & 0 & 1 & 2 & 2 & 2 & 1 & NS \\
\hline White clover & 16 & 12 & 5 & 9 & 9 & 2 & $*$ \\
\hline Dead material & 11 & 16 & 30 & 31 & 37 & 4 & ** \\
\hline In vitro digestibility & 68.6 & 67.9 & 66.6 & 65.0 & 64.1 & 1.9 & NS \\
\hline
\end{tabular}

Table? Rates of herbage accumulation (kg DM/ha/d) during treament period (I September 1986-12 January 1987)

\begin{tabular}{|c|c|c|c|c|c|c|c|}
\hline & $\begin{array}{c}\text { Hard } \\
\text { grazing } \\
+ \text { topping }\end{array}$ & $\begin{array}{r}\text { Hard } \\
\text { grazing }\end{array}$ & $\begin{array}{r}\text { Lax } \\
\text { grazing }\end{array}$ & $\begin{array}{l}\text { Partial } \\
\text { reseeding }\end{array}$ & $\begin{array}{l}\text { Complete } \\
\text { reseeding }\end{array}$ & SED & Sign \\
\hline Grass leaf & 42 & 27 & 11 & 12 & 10 & 8.0 & $* * *$ \\
\hline $\begin{array}{l}\text { Grass pseudostem } \\
\text { Grass reprod. stem }\end{array}$ & $\begin{array}{l}5 \\
6\end{array}$ & $\begin{array}{r}4 \\
15\end{array}$ & 31 & $\begin{array}{r}4 \\
24\end{array}$ & 19 & $\begin{array}{l}3.3 \\
7.6\end{array}$ & $\underset{* *}{N S}$ \\
\hline $\begin{array}{l}\text { White clover } \\
\text { Green herbage }^{a} \\
\text { Dead herbage }\end{array}$ & $\begin{array}{r}11 \\
64 \\
-3\end{array}$ & $\begin{array}{r}10 \\
56 \\
3\end{array}$ & $\begin{array}{c}7 \\
50 \\
10\end{array}$ & $\begin{array}{r}5 \\
45 \\
15\end{array}$ & $\begin{array}{r}5 \\
37 \\
17\end{array}$ & $\begin{array}{r}4.0 \\
10.5 \\
5.8\end{array}$ & NS \\
\hline Total $^{6}$ & 61 & 59 & 60 & 60 & 54 & 9.4 & NS \\
\hline
\end{tabular}

Green herbage $=$ grass components + clover

Total $=$ green + dead herbage

Table 3: Proportion of tagged reproductive (reprod.) tillers intact at flowering, intact reproductive tiller density (12 January $1987)$ and viable ryegrass seed on soil surface (2 February 1967).

\begin{tabular}{|c|c|c|c|c|c|c|c|}
\hline & $\begin{array}{c}\text { Hard } \\
\text { grazing } \\
+ \text { topping }\end{array}$ & $\begin{array}{l}\text { Hard } \\
\text { grazing }\end{array}$ & $\begin{array}{c}\text { Lax } \\
\text { grazıng }\end{array}$ & $\begin{array}{l}\text { Partial } \\
\text { reseeding }\end{array}$ & $\begin{array}{l}\text { Complete } \\
\text { reseeding }\end{array}$ & SED & Sign \\
\hline Proportion of reprod. & 2 & 5 & 55 & 80 & 95 & 11 & $H$ \\
\hline $\begin{array}{l}\text { tillers died or } \\
\text { defoliated } \\
\text { Reprod. tiller density }\end{array}$ & 363 & 1120 & 1575 & 2533 & 2149 & 440 & tr \\
\hline $\begin{array}{l}\left.\text { (tillers } / \mathrm{m}^{2}\right) \\
\text { Viable seed density } \\
\left(\text { seeds } / \mathrm{m}^{*}\right)\end{array}$ & 240 & 1290 & 2890 & 5320 & 11900 & 2540 & 11 \\
\hline
\end{tabular}

Table 4: Rate of herbage accumulation ( $\mathrm{kg} \mathrm{DM} / \mathrm{ha} / \mathrm{d}$ ) and total herbage accumulated (t DM/ha) during late summer-early winter (19 January $1987=1$ July 1967).

\begin{tabular}{lccccccc}
\hline & $\begin{array}{c}\text { Hard grazing } \\
+ \text { topping }\end{array}$ & $\begin{array}{c}\text { Hard } \\
\text { grazıng }\end{array}$ & $\begin{array}{c}\text { Lax } \\
\text { grazing }\end{array}$ & $\begin{array}{c}\text { Partial } \\
\text { reseeding }\end{array}$ & $\begin{array}{c}\text { Complete } \\
\text { reseeding }\end{array}$ & SED & Sign \\
\hline $\begin{array}{l}\text { Rate of accumulation } \\
\text { Total accumulation }\end{array}$ & 38 & 40 & 47 & 50 & 51 & 3.4 & $*$ ** \\
\hline
\end{tabular}

\section{Seedling estátishment}

Mortality of ryegrass seedlings during late summer-early winter period was high (range 40-75\%) for all treatments (Figure 1). 'seedling loss was highest where initial seedling density and competition from resident herbage was high.

\section{DISCUSSION}

The observation that hard and/or frequent defoliation of ryegrass/white clover pasture in late spring-early summer suppresses development of reproductive tillers and encourages 


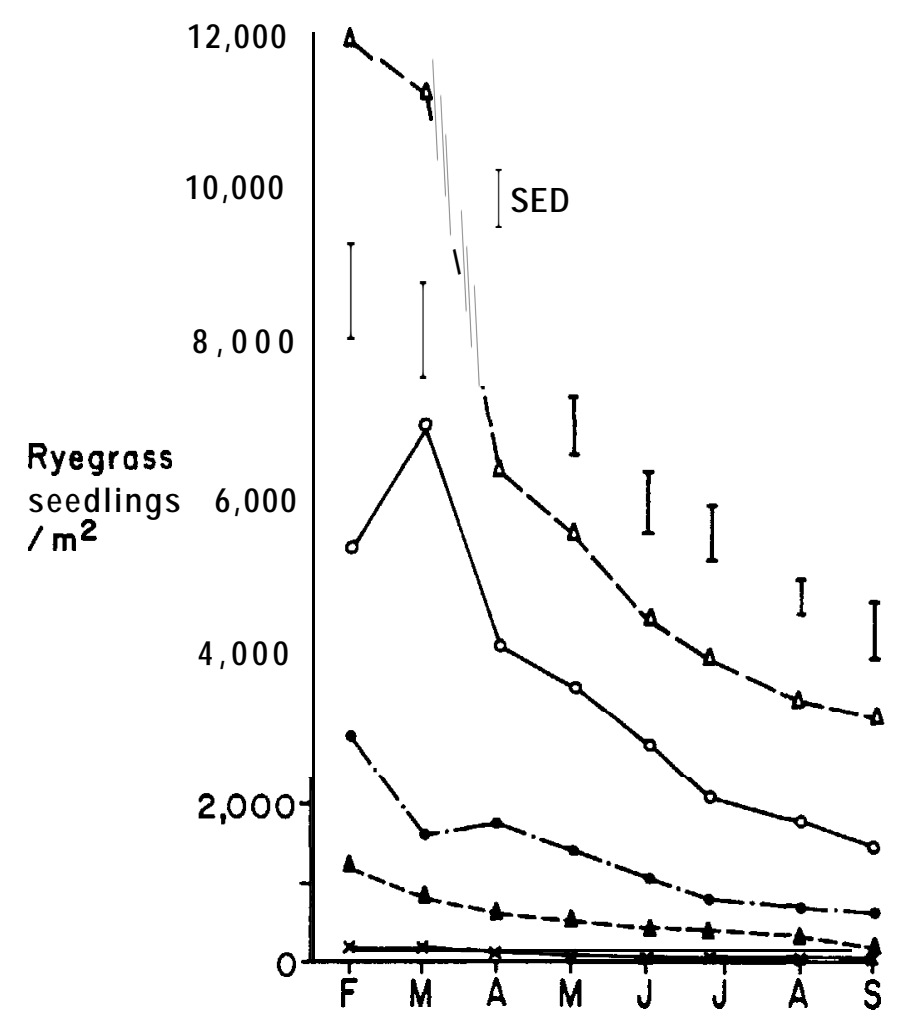

Figure 1: Ryegrass seedling density (plants $\left./ \mathrm{m}^{*}\right)$ for hard grazed with topping $(\mathrm{x}-\mathrm{x})$, hard grazed $(\boldsymbol{\Lambda} \ldots \mathbf{\Lambda})$, laxly grazed

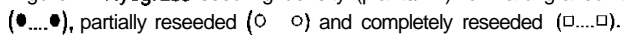

growth of grass leaf and white clover has been demonstrated in numerous studies (eg Korte et al. 1982). Associated with the encouragement of grass leaf and white clover by intense defoliation is a positive effect on sward quality (Thomson et al. 1984). This has given rise to the recommendation that an important objective of spring management is the "maintenance of sward quality going into the summer (Thomson et al. 1984). In practice this involves hard and/or frequent grazing, topping and silage conservation.

This study demonstrates the consequences of such practices on propagaion of ryegrass from seed. Early defoliation of reproductive tillers greatly reduced reseeding of ryegrass and significantly reduced the possibility of propagation from seed. Survival of perennial ryegrass under this management is therefore almost completely reliant on tillering.

In ryegrass/white clover dairy pastures reliance on vegetative propagaion appears to be inadequate to maintain sward stability. This is illustrated by the low tiller densities $\left(2-5000 / \mathrm{m}^{2}\right.$, Bryant \& L'Huillier 1986) and high levels of self sown grasses and broadleaf weeds that are often encountered. Loss of whole plants by "pulling", trampling, dung and urine contamination and insect attack can be high under intensive dairy cattle grazing (Wade \& Baker 1979). Currently, the ryegrass plant losses are replaced by the regular and increasing practice of pasture renovation by direct drilling (Thorn et al. 1986).

In contrast, lax grazing and partial or complete reseeding allowed a high proportion of reproductive tillers to develop to maturity. As a result, high seed and germinated seedling densities were observed in these treatments. This in turn was associated with a greatly 
increased herbage accumulation during late summer-early winter. These advantages could be readily incorporated into existing farm practices. Like silage conservation, a designated area could be removed from the grazing rotation during the period of reproductive tiller development. The size of this area would be flexible varying from year to year depending on the amount of pasture surplus to cow requirements and the quantity of silage required. For example, $70 \%$ of the farm may be in the grazing rotation with $15-20 \%$ for silage and $10-15 \%$ left to reseed. A 5-10 year reseeding rotation around the farm could thus be established.

Timing of grazing before "shutting up" for reseeding is important. The growth of reproductive tillers in the base of the pasture should be monitored. When they reach grazing height (mid-late October) the area should be grazed only very laxly over the following 2-3 weeks and then removed from the grazing rotation. When seed is shed readily from a seedhead (mid-January) the area is ready for regrazing.

The reseeded area could be regarded as a summer crop and strip grazed in conjunction with good quality pasture. The area would provide 4-5 t DM/ha in January-February which on an average farm would supply $5 \mathrm{~kg} \mathrm{DM} / \mathrm{cow} / \mathrm{day}$ for 20-30 days. Management of pasture during seedling establishement should follow recommendations for newly renovated pastures (refer Thorn et al. 1987)

\section{CONCLUSIONS}

1. Allowing reseeding of ryegrass/white clover pastures can result in substantial ryegrass seedling establishment.

2. Intense defoliation during late spring prevents almost all reseeding.

3. Reseeding of designated areas of a farm could be incorporated into present farm management.

\section{References}

Bryant A.M., L'Huillier P.J. 1966. Better use of pastures. Proceedings Ruakura Farmers' Conference 38: 43-51.

Chancellor R.J. 1979. Grass seeds beneath pastures. pp 147-50. Changes in Sward Composition and Productivity. Occasional Symposium No. 10 British Grassland Society.

Korte C.J., Watkin B.R., Harris W. 1982. Use of residual leaf area index and light interception as criteria for spring grazing management of a ryegrass dominant pasture. NZ Journal of Agricultural Research 25: 309-319.

Lancashire J.A. 1985. Quality pasture production for the dairy industry. pp 9-26. In: Phillips T.I. (Ed.). The Challenge: Efficient Dairy Production. Australian and New Zealand Societies of Animal Production.

Langer R.H.M. 1973. Growth of grasses and clovers. pp 41-64. In Langer R.H.M. (Ed.). Pastures and Pasture Plants. A.H. \& A.W. Reed, Wellington, NZ.

Thorn E.R., Sheath G.W., Bryant A.M. 1986. Survival of overdrilled ryegrass in dairy pastures containing paspalum. Proceedings NZ Grassland Association 47: 141-I 48.

Thorn E.R., Prestidge R.A., Barker G.M. 1987. Pasture establishment on the dairy farm. Proceedings Ruakura Farmers' Conference 39: $50-52$

Thompson K.. Grime J.P. 1979. Seasonal variation in the seed banks of herbaceous species in ten contrasting habits. Journal of Ecology 67: 893.921.

Thomson N.A., Lagan J.R., McCallum D.A. 1984. Herbage allowance, pasture quality and milkfat production as affected by stocking rate and conservation policy. Proceedings NZ Society of Animal Production 44: 67-70.

Wade M.H. Baker R.D. 1979. Does periodic defoliation predispose perennial ryegrass swards to deterioration. In Charles A.H., Haggar R.J. (Ed.). Changes in Sward Composition and Productivity. Occasional Symposium of the British Grassland Society 10: 68 